\title{
DWIE ROCZNICE W KALISZU (1960-1966): OSIEMNAŚCIE WIEKÓW KALISZA I TYSIĄCLECIE POLSKI
}

\author{
TWO ANNIVERSARIES IN KALISZ (1960-1966): \\ EIGHTEEN CENTURIES OF KALISZ AND MILLENNIUM OF POLAND
}

The Archaeological Laboratory of the Institute of Archeology and Ethnology of the Polish Academy of Sciences in Kalisz is over 60 years old and participated in undertakings connected with two jubilees - Millennium of the Baptism of Poland or Millennium of the Polish State and the Eighteen Centuries of Kalisz. In this time, the head of Lab in Kalisz was archaeologist Krzysztof Dąbrowski. The excavations at the archaeological site of the Roman period in Piwonice near Kalisz was related to the role of archaeological sources in the identification of Kalisz as Ptolemy's Kalisia. The greatest discoveries of the fifties and sixties of the 20th century in Kalisz concerned the research of Millennium project in the area of Zawodzie-Stronghold.

KEY WORDS: Millennium program, Eighteen Centuries of Kalisz, excavations at Kalisz, Krzysztof Dąbrowski

...Specyficznej atmosferze Kalisza, manifestujacej się powszechnym zainteresowaniem Mieszkańców Miasta jego przeszłościq oraz głęboka troska miejscowych Władz o rozwój badań naukowych, przypisać należy osiagnięcia archeologów tu działajacych... - Krzysztof Dąbrowski, twórca i wieloletni kierownik Stacji i Pracowni Archeologicznej w Kaliszu (1931-1979)

Oba symboliczne jubileusze - millenijny - Tysiąclecia Chrztu Polski, czy też jego świecki odpowiednik lub konkurent Tysiąclecia Państwa Polskiego, a także bardziej lokalna rocznica - Osiemnastu Wieków Kalisza, doczekały się w Kaliszu stosownych obchodów, które na polu naukowym dały zachętę do podsumowań osiągnięć w zakresie historii i archeologii regionu. Obchody, dawniej i obecnie (również te po pięćdziesięciu latach), były organi- zowane przez instytucje świeckie i kościelne (ostatnio już bez rywalizacji o prymat).

Pracownia Archeologiczna (dziś Kaliskie Stanowisko Archeologiczne) Instytutu Archeologii i Etnologii Polskiej Akademii Nauk ma już ponad 60 lat i przez cały ten czas zachowała główne kierunki badań i aktywności nastawione na zagadnienia ochrony i konserwatorstwa archeologicznego dla pożytku nauki i społeczeństwa Kalisza [por. 
Kędzierski (red.) 2016; szczególnie Baranowski 2016a, skąd pochodzą fragmenty niniejszego tekstu].

Mocną stroną kaliskiej placówki, podobnie jak i całego Instytutu, była zawsze interdyscyplinarność, wielość i różnorodność materiałów zabytkowych pochodzących z wykopalisk, jak również uprawianie wielu form działalności, w tym popularyzacyjnej, a także pozostawanie w stałym kontakcie $\mathrm{z}$ miejscowym społeczeństwem i z lokalnymi władzami (por cytat we wstępie). Być może brzmi to jak slogan, lecz w przypadku Kalisza ma swoją konkretną treść i znaczenie.

W roku 1950 wymieniano listy pomiędzy Ministerstwem, Komitetem Badań oraz Kierownictwem Prac Wykopaliskowych w Kaliszu w osobie Michała Drewki (1887-1964), na temat organizacji konferencji archeologicznej w Kaliszu, której głównym tematem miał być program badań archeologicznych w mieście i okolicach.

9 września 1950 roku Ryszard Kiersnowski - historyk i wybitny numizmatyk (1925-2006), jako zastępca Aleksandra Gieysztora (1916-1999), prowadzącego Kierownictwo Badań nad Początkami Państwa Polskiego wysłał do Michała Drewki list z prośbą o tezy do jego referatu pt. „Problematyka i program badań archeologicznych w Kaliszu". Dwudniowa konferencja na ten temat odbyła się 4 i 5 listopada 1950 roku w kaliskim Ratuszu i w Sali Teatru im. W. Bogusławskiego.

9 marca 1951 roku doszło do spotkania Kazimierza Majewskiego, Bronisława Bilińskiego, Zdzisława Rajewskiego oraz kierownika prac W Kaliszu - Michała Drewki (jako pracownika PMA). Spotkanie zaowocowało zaprojektowaniem wykopalisk w Kaliszu, głównie na Tyńcu. Należy wspomnieć, że Tyniec w Kaliszu - idealny punkt strategiczny - był brany pod uwagę jako miejsce, gdzie ewentualnie należałoby szukać naczelnego grodu opola (Drewko 1953).

Ze względu na tematykę całego tomu pominięto tutaj historię narodzin Instytutu Historii Kultury Materialnej (por. m.in. Lech 1997-1998), wskazać jednak wypada, że w Instytucie, w skład Działu I - Archeologii Polski, od samego początku (od 1953 r.) wchodziła Stacja Archeologiczna w Kaliszu. Instytut bowiem przejął większość placówek byłego Kierownictwa Badań nad Początkami Państwa Polskiego w Zarządzie Ochrony i Konserwacji Zabytków Ministerstwa Kultury i Sztuki, w tym wszystkie jego agendy terenowe. Badaniami w Ka- liszu zajmowała się wówczas również Pracownia Historii Osadnictwa.

W 1954 roku w strukturze Instytutu Historii Kultury Materialnej, poza placówką w Kaliszu, istniały jeszcze inne stacje archeologiczne: w Grodach Czerwieńskich, Wiślicy, Łęczycy, Bonikowie, Gieczu, Kołobrzegu, Kruszwicy, w Poznaniu na grodzie, w Poznaniu-Katedrze i w Wolinie.

Wykopaliska na Tyńcu w Kaliszu w 1950 roku prowadzone przez Michała Drewkę, z ramienia Państwowego Muzeum Archeologicznego w Warszawie, poprzedzily zorganizowane przez to $\mathrm{Mu}$ zeum, zakrojone na szeroką skalę poszukiwania powierzchniowe nad Prosną. Michał Drewko był twórcą i pierwszym Kierownikiem Stacji Archeologicznej w Kaliszu, już w ramach IHKM PAN.

Po II Wojnie Światowej w Polsce do archeologii trafiło wielu wartościowych ludzi, którzy w ,normalnych” czasach działaliby w zupełnie innych dziedzinach, na przykład w gospodarce, wojsku, polityce. Jedną z takich postaci był Krzysztof Dąbrowski (Baranowski 1990; Herbich 2016). Był on prawdziwym animatorem i duszą prac archeologicznych w Kaliszu (ryc. 1). W Stacji IHKM pojawił się w roku 1951. Kierował nią 20 lat - od 1954 do 1974 r., kiedy objął stanowisko Dyrektora Państwowego Muzeum Archeologicznego w Warszawie (po Zdzisławie Rajewskim).

Tylko nieco później od K. Dąbrowskiego w Stacji Archeologicznej w Kaliszu znalazły się: Marta Młynarska, Iwona Ślaska (Dąbrowska) oraz Ryta Kozłowska, które działały tam bardzo aktywnie (ryc. 2). Marta Młynarska, zajmująca się zagadnieniami formowania się i rozwoju miasta lokacyjnego oraz dziejami jego kościołów, stale publikuje prace dotyczące archeologii lub historii wczesnego i pełnego średniowiecza Kalisza (Młynarska-Kaletynowa m. in. 1998; 2000).

$\mathrm{Na}$ wielu zagrożonych stanowiskach archeologicznych w Kaliskiem prowadzono równolegle prace ratownicze. Badano liczne stanowiska z okresu wpływów rzymskich, na przykład Piwonice pod Kaliszem (Dąbrowski 1958; Dąbrowski, Kozłowska 1959). Jednym z celów było podkreślenie podstaw identyfikacji Kalisza ze starożytną Kalisia (por. także Biliński 1955; 1962).

Innym kierunkiem prac były studia nad przedlokacyjnymi początkami miasta Kalisza, czego najlepszym przykładem są badania na terenie osady na Starym Mieście, które zostały zapoczątkowane podczas badań millenijnych. W latach 1953-1957 na te- 
renie Starego Miasta w Kaliszu trwały wykopaliska pod kierunkiem Teresy Uzdowskiej, a w mieście lokacyjnym pod kierunkiem Marty Młynarskiej i Wiesławy Szenicowej (Młynarska 1960a; 1960b; por. również Kędzierski, Wyczółkowski 2016). Prace na Starym Mieście są znowu prowadzone od kilkunastu lat, dzięki corocznemu dofinansowaniu przez Urząd Miasta.

Należy wyjaśnić, że prace terenowe i studia archeologiczno-historyczne w drugiej połowie lat pięćdziesiątych i początkach sześćdziesiątych XX wieku w Kaliszu wiązały się z przygotowaniami do dwóch wspomnianych jubileuszy, nierozerwalnie $\mathrm{z}$ sobą związanych i czerpiących inspiracje z tych samych źródeł, a jednocześnie korzystających z zaangażowania i zapału tych samych osób.
Już w 1948 roku utworzono Komitet Organizacyjny obchodów jubileuszu 1800-lecia Kalisza, jednak do roku 1956, gdy wznowiono jego działalność, brak było materiałów naukowych umożliwiających przygotowanie uroczystości na wysokim poziomie merytorycznym (Kozłowska 1968, 397). Wytyczono wtedy główne kierunki działania: popularyzowanie 1800-letniej historii miasta (w czym nawiązywano do wzmianki o Kalisii w dziele Ptolemeusza); prowadzenie działalności wydawniczej; popieranie rozwoju miasta w kwestii inwestycji gospodarczych i mieszkaniowych oraz remontów. Jak widać, niektóre punkty wyraźnie nie pasowały do charakteru obchodów, ale w dziedzinie nauki skupiono się przede wszystkim na badaniach, publikacjach i sympozjach.

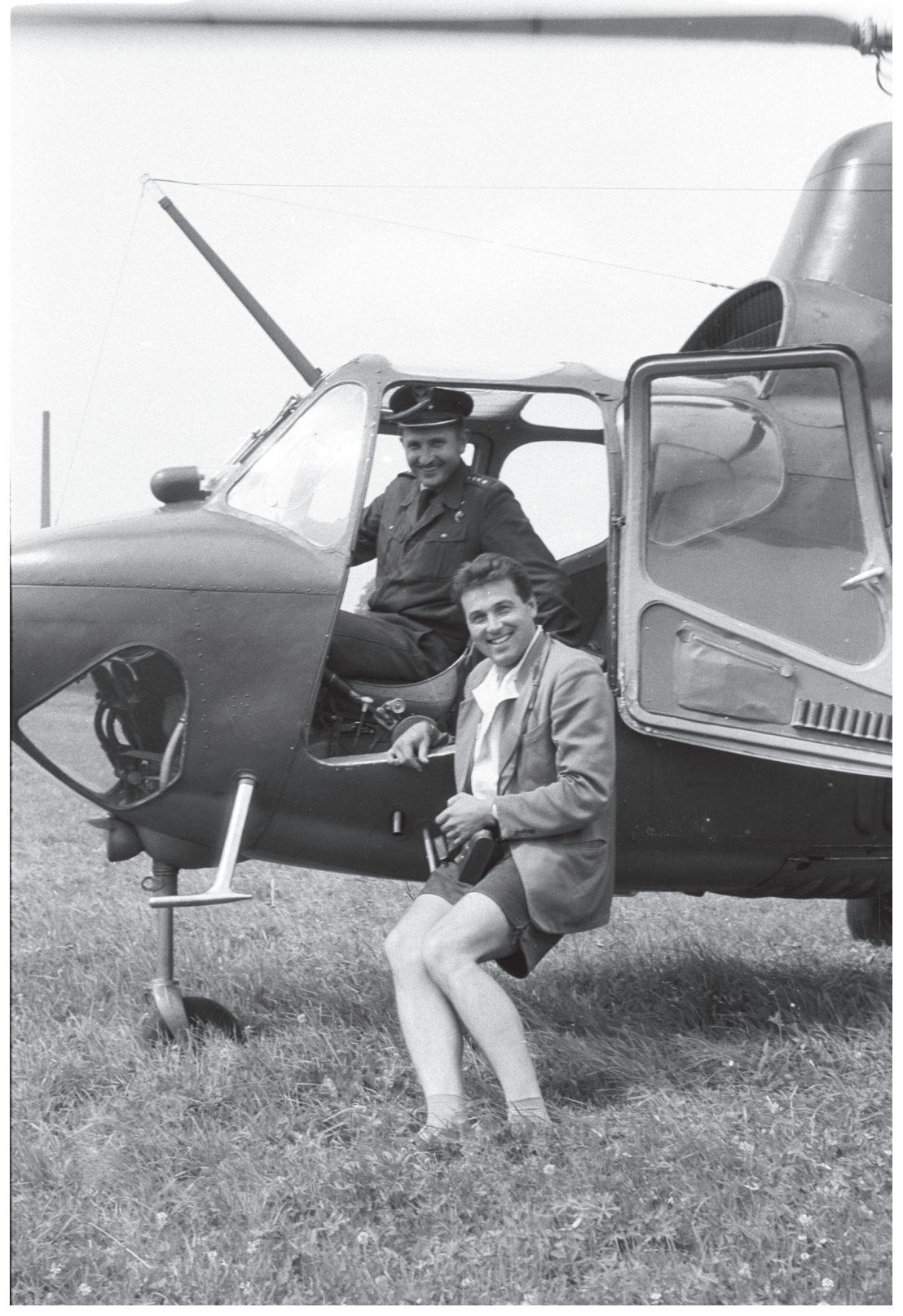

Ryc. 1. Krzysztof Dąbrowski w trakcie ,zwiadu” helikopterem. Kalisz, lata sześćdziesiąte XX w.

Z Archiwum Kaliskiego Stanowiska Archeologicznego IAE PAN

Fig. 1. Krzysztof Dąbrowski during an aerial recon. Kalisz, the 1960s. From the Kalisz Archaeological Site Archives of the Institute of Archaeology and Ethnology of the Polish Academy of Sciences 


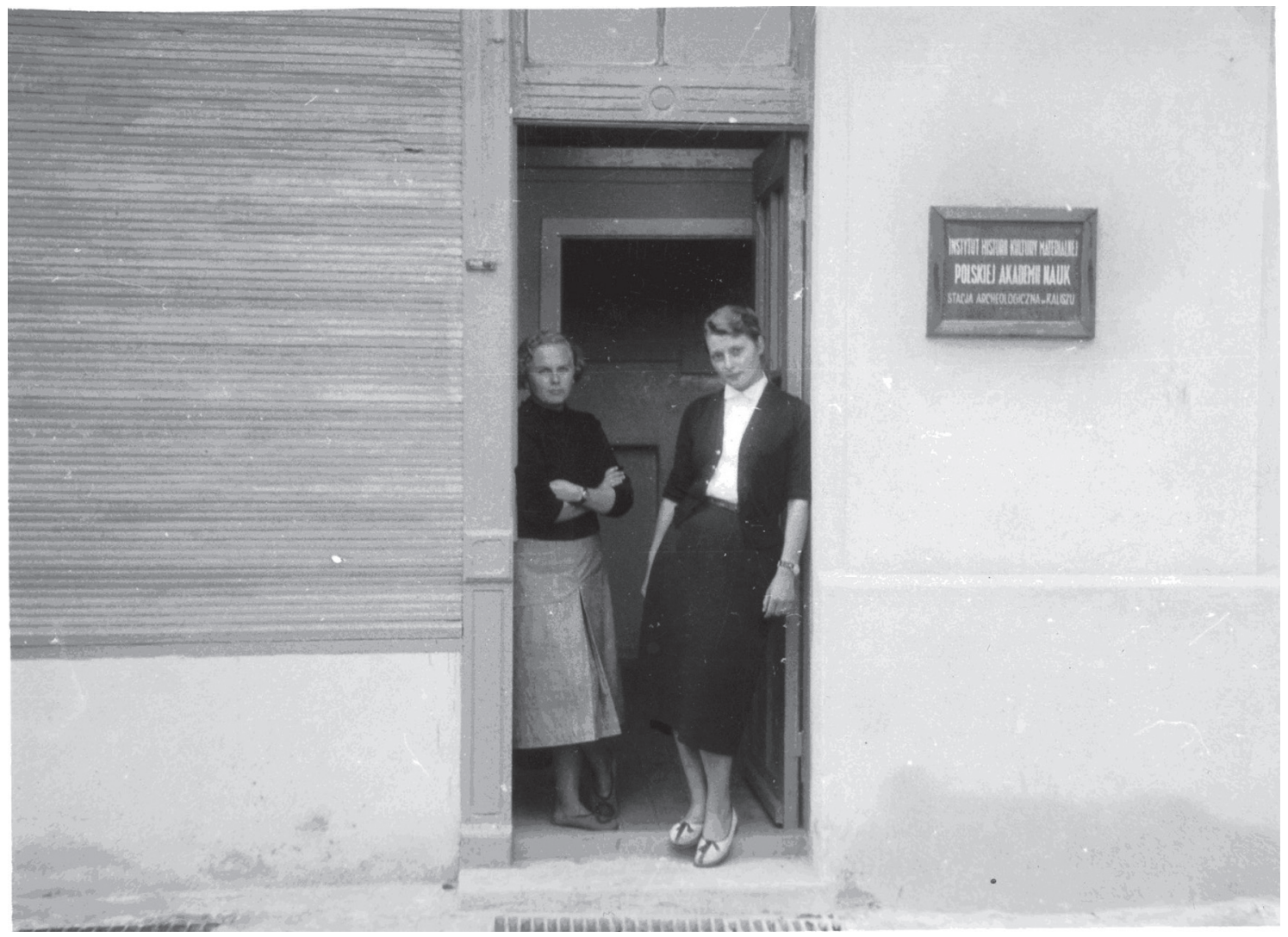

Ryc. 2. Ryta Kozłowska i Iwona Dąbrowska w Kaliszu. Archiwum KSA IAE PAN

Fig. 2. Ryta Kozłowska and Iwona Dąbrowska in Kalisz. The Kalisz Archaeological Site Archives of the Institute of Archaeology and Ethnology of the Polish Academy of Sciences

Krzysztof Dąbrowski był aktywnym organizatorem szeregu międzynarodowych sesji naukowych w Kaliszu, związanych z przygotowywaniem obchodów „Osiemnastu Wieków Kalisza”. Pierwszym zwiastunem powrotu do idei obchodów było zorganizowanie 6 grudnia 1956 r. jednodniowej sesji naukowej poświęconej problematyce starożytnego i średniowiecznego Kalisza, połączonej z IV Walnym Zjazdem delegatów Polskiego Towarzystwa Archeologicznego. Współorganizatorem sesji był Komitet Obchodu XVIII wieków Kalisza. Wzięli w niej udział archeolodzy z Czech.

Władze kościelne w Polsce rozpoczęły starania o odpowiednie uczczenie Tysiąclecia Chrztu już w roku 1956. Aparat władzy państwowej zareagował na to ideą obchodów Tysiąclecia Państwa Polskiego (1960-1966). Wiedza o najdawniejszej historii Kalisza znacznie wówczas zyskała, ponieważ w ślad za programem millenijnym szły pieniądze na badania naukowe, a K. Dąbrowski umiał je pożytecznie wykorzystać. Oficjalny początek całych obchodów Millenium Państwa Polskiego zainaugurowano właśnie w Kaliszu 16 lutego 1960 r., ale faktyczny program badań został nakreślony już w roku 1949 przez Aleksandra Gieysztora jako szefa Kierownictwa Badań nad Początkami Państwa Polskiego. Krzysztof Dąbrowski i Aleksander Gieysztor ściśle ze sobą współpracowali w przygotowaniach i realizacji obchodów obu jubileuszy. Duży wkład wniósł również Witold Hensel.

Obok dwóch symbolicznych jubileuszy do obchodów włączono jeszcze trzeci: 700 lat lokacji miasta - kaliski przywilej lokacyjny na prawie średzkim nadał Bolesław Pobożny przypuszczalnie w roku 1257.

Najdonioślejsze odkrycia $\mathrm{z}$ lat pięćdziesiątych i sześćdziesiątych ubiegłego wieku w Kaliszu to efekt badań Krzysztofa i Iwony Dąbrowskich na terenie grodziska na Zawodziu. Największe znaczenie ma odkrycie reliktów romańskiej kolegiaty pod wezwaniem św. Pawła, wraz z przykościelnym cmentarzem (Dąbrowska 1960; 1968; Dąbrowski 1962a; 1962b). Rekonstrukcją bryły kolegiaty zajmowali się historycy architektury, między innymi Bohdan Guerquin (1904-1979; por. Przyłęcki 2006). Zarówno w jego twórczości, jak i w twórczości Aleksan- 
dra Gieysztora trudno wskazać publikacje odnoszące się ściśle jedynie do Kalisza. Jednak w zakresie formułowania problematyki i pytań badawczych oraz ukierunkowywania studiów owi dwaj wybitni intelektualiści wywarli niezaprzeczalny wpływ na kształtowanie młodszych badaczy i prace naukowe realizowane w Kaliszu.

Rezultaty badań wykopaliskowych były natychmiast pożytkowane do organizowania sympozjów, jak konferencja, która odbyła się 8 września 1958 r. w Kaliszu staraniem IHKM PAN oraz Komitetu Obchodu XVIII wieków Kalisza. Referat wygłoszony przez K. Dąbrowskiego nosił tytuł: „O wynikach badań archeologicznych uzyskanych na Zawodziu w 1958 roku”, a B. Guerquina: „Zagadnienie próby interpretacji odkrytych na Zawodziu budowli kamiennych". Wtedy też zaproponowano stworzenie rezerwatu-muzeum na grodzisku w Kaliszu.

W roku 1959 Uniwersytet Warszawski i Polska Akademia Nauk zorganizowały w Kaliszu Międzynarodowe Seminarium Historyczne na temat początków rzemiosła i miast w Polsce. W Seminarium wzięło udział kilkudziesięciu badaczy z 16 krajów $\mathrm{z}$ całego świata.

Jest to jeden z przykładów talentu organizacyjnego K. Dąbrowskiego, który w trudnych warunkach lat pięćdziesiątych potrafił prowadzić żywe zagraniczne kontakty naukowe (również z badaczami „Świata Zachodniego”). Była to okazja do zaprezentowania kaliskich odkryć.

Wyniki badań millenijnych, z lat 1958-1965, potwierdziły znaczną rolę Kalisza jako jednego z głównych ośrodków wczesnośredniowiecznej Polski, dostarczyły wielkiej liczby przedmiotów zabytkowych nierzadko o wybitnych walorach wystawienniczych oraz ukierunkowały na kilkadziesiąt lat badania archeologiczne i towarzyszące im studia interdyscyplinarne w rejonie Kalisza, między innymi kwestie środowiska naturalnego i wzajemnych relacji ze zjawiskami kulturowymi (Dąbrowski et al. 1962).

Podczas ostatnich 50 lat kontynuowano zasadnicze wątki badań nad przeszłością Kalisza. W zakresie historii ośrodka centralnego na Zawodziu w Kaliszu, dokonania K. Dąbrowskiego i jego zespołu zostały nieco wzbogacone przez późniejsze prace (na temat obecnego stanu wiedzy o archeologii Kalisza por. Baranowski 2015; 2016b; 2016c). Nadal jednak nie została ukończona naukowa monografia tego obiektu, która jest poważnie zaawan- sowana w ramach projektu Origines Polonorum, i w tamtej serii wydawniczej ma stanowić jeden $\mathrm{z}$ tomów.

Chociaż nowsze badania niejednokrotnie zmieniły lub uściśliły dawne ustalenia, zwłaszcza w zakresie datowania bezwzględnego, jednak w niczym to nie umniejsza znaczenia prac, o których była mowa.

Gród w dzielnicy Zawodzie w Kaliszu użytkowano już w okresie plemiennym. Jego funkcja w tamtym czasie bywa dyskutowana. Wysuwano nawet przypuszczenia o kultowym charakterze tego obiektu. Niepodważalne ślady praktyk pogańskich na Zawodziu pochodzą jednak tylko z cmentarzyska. Przeważa opinia o grodzie jako siedzibie władzy świeckiej.

Zmiany w zakresie wierzeń religijnych manifestują się na terenie grodu, obejmującego u progu XI wieku kilkakrotnie większy niż dawniej obszar. W tym czasie powstała budowla, której pozostałości odkryto pod reliktami romańskiej kolegiaty pod wezwaniem świętego Pawła. Prace wykopaliskowe w latach pięćdziesiątych i sześćdziesiątych odsłoniły niemal kompletny zarys podwalin kościoła drewnianego, jednak nie został on tak zinterpretowany, a jego część (według T. Baranowskiego - sztucznie) włączono do tak zwanego grobowca Mieszka Starego. Istotnym nowszym uzupełnieniem prac Dąbrowskich na grodzie w Kaliszu jest odsłonięcie palowania zastosowanego pod fundamentami pierwszej kamiennej kolegiaty.

Dotychczas nie wiadomo, jakie wezwanie nosiła najwcześniejsza, drewniana świątynia w Kaliszu. Z kościoła drewnianego na grodzie zachowały się jedynie ślady drewnianych belek podwalin oraz zarysy wkopu fundamentowego. Była to budowla o prostokątnej, prawie kwadratowej nawie oraz prostokątnym - prawie kwadratowym prezbiterium. Była zorientowana - $\mathrm{z}$ prezbiterium - na wschód. Zapewne przypominała znane ze Skandynawii kościoły drewniane, a także dzisiejszy zabytkowy kościół św. Wojciecha na Zawodziu. Odbiegała jednak od nich swymi niewielkimi rozmiarami.

Takich budowli z pewnością było na terenie Polski więcej, jednak z uwagi na wznoszenie w tych samych miejscach bardziej okazałych i prestiżowych kościołów kamiennych brak jest o tym danych. W przypadku Kalisza pozostałości konstrukcji drewnianej zostały zachowane, ponieważ nawa romańskiej kolegiaty objęła je w swym wnętrzu. Niektóre z pochówków na cmentarzu przykościel- 
nym lub usytuowane wewnątrz kościoła, zwłaszcza te przecięte wkopami fundamentowymi architektury kamiennej, mogą się wiązać z najstarszym założeniem drewnianym.

Można zauważyć, że w Kaliszu co pewien czas podsumowywano stan badań historyczno-archeologicznych, wyciagając również wnioski w zakresie programowania przyszłych prac. Począwszy od roku 1950 i wspomnianej konferencji zorganizowanej w kaliskim ratuszu przez Michała Drewkę, co kilka lub kilkanaście lat takiej problematyce poświęcano sympozja, wydając w związku z tym materiały pokonferencyjne, stanowiące ważne ujęcia monograficzne dziejów miasta.

Najważniejszym podsumowaniem pewnego etapu badań nad przeszłością Kalisza były w roku 1960 obchody symbolicznych „Osiemnastu Wieków Kalisza”, rozpoczynające uroczystości Tysiąclecia Państwa Polskiego. Międzynarodowa sesja naukowa na temat historii Kalisza w okresie kształtowania się Państwa Polskiego odbyła się 25 czerwca 1960 r. z inicjatywy Społecznego Komitetu Obchodu XVIII wieków Kalisza oraz IHKM PAN. Główny referat - „Kalisz w okresie kształtowania się Państwa Polskiego" wygłosił A. Gieysztor, a K. Dąbrowski i W. Stopiński scharakteryzo- wali „Zastosowanie metody elektryczno-oporowej w badaniach archeologicznych" (ryc. 3). Krzysztof Dąbrowski był bowiem prekursorem zastosowania metod geofizycznych na gruncie polskim (Herbich 2016).

W latach 1960-1962 pod redakcją Aleksandra Gieysztora i Krzysztofa Dąbrowskiego ukazały się trzy tomy publikacji Osiemnastu wieków Kali$s z a \mathrm{z}$ bardzo wartościowymi opracowaniami. Wystarczy wymienić „Kalisz na tle wczesnośredniowiecznej sieci drogowej” Teresy Wąsowiczówny (1960), „Genezę regionu kaliskiego" Stanisława Trawkowskiego (1962) czy też „Proces lokacji Kalisza w XIII i 1 poł. XIV w." Marty Młynarskiej (1960).

Kontynuacją wspomnianego naukowego wydawnictwa jest „Rocznik Kaliski” wydawany od 1968 r. przez Kaliski Oddział Polskiego Towarzystwa Historycznego. Pierwsze posiedzenie komitetu redakcyjnego „Rocznika Kaliskiego” odbyło się 6 marca 1964 r., uczestniczyli w nim Krzysztof Dąbrowski, Aleksander Gieysztor, Gerard Labuda, Wiktoria Kunicka (sekretarz) i Władysław Rusiński (redaktor). Na spotkaniu ustalono nazwę wydawnictwa i postanowiono traktować je jako ciag dalszy Osiemnastu wieków Kalisza.

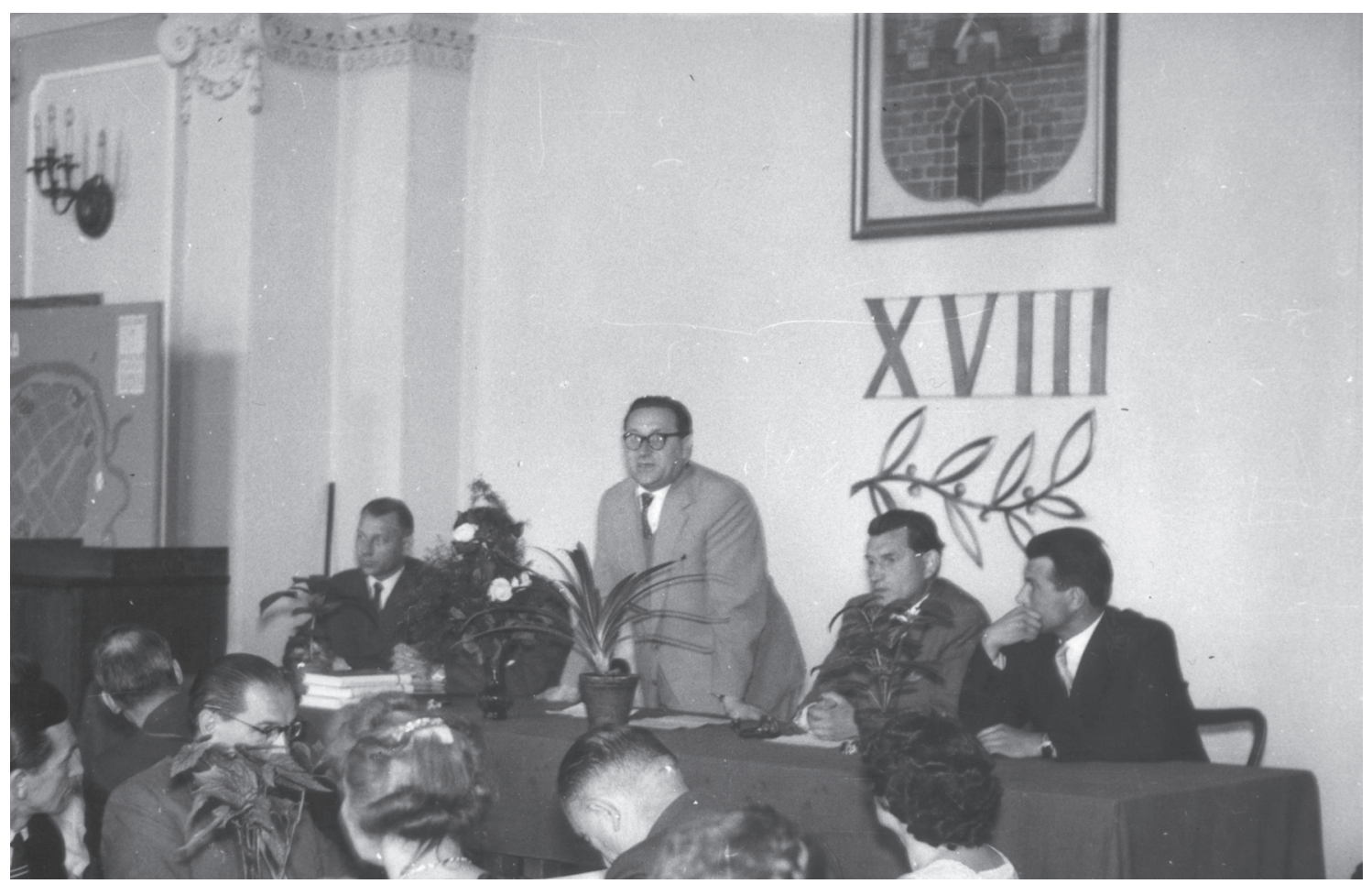

Ryc. 3. Uroczysta sesja obchodów XVIII wieków Kalisza. Kalisz 1960. Przemawia Witold Hensel. Archiwum KSA IAE PAN

Fig. 3. Eighteen centuries of Kalisz celebration event. Kalisz 1960. Speech by Witold Hensel. The Kalisz Archaeological Site Archives of the Institute of Archaeology and Ethnology of the Polish Academy of Sciences 


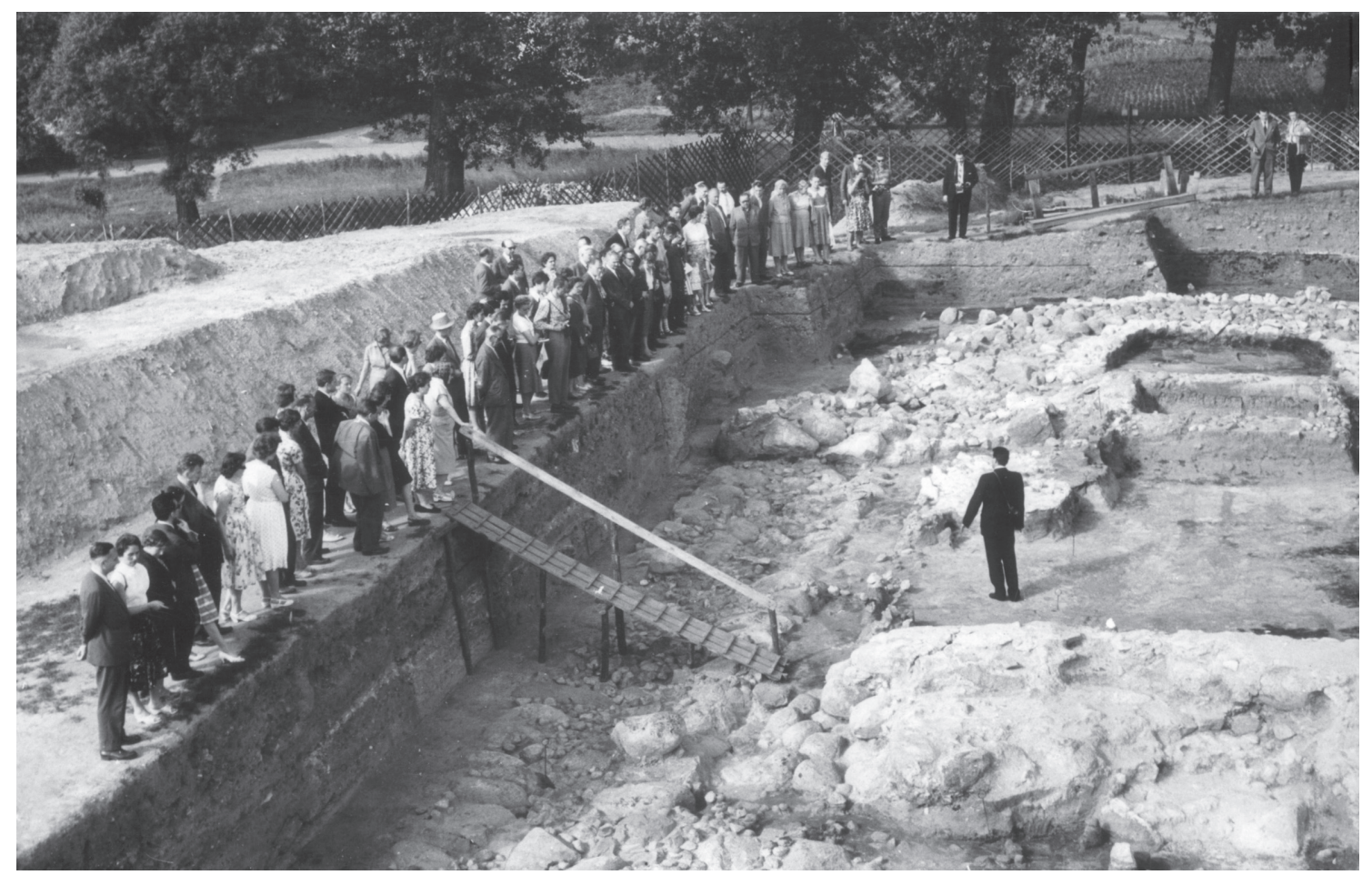

Ryc. 4. Krzysztof Dąbrowski na tle reliktów romańskiej kolegiaty pod wezwaniem Św. Pawła podczas międzynarodowego sympozjum w roku 1959 r. Archiwum KSA IAE PAN

Fig. 4. Krzysztof Dąbrowski and the relics of the Romanesque collegiate church of St. Paul during an international symposium in 1959. The Kalisz Archaeological Site Archives of the Institute of Archaeology and Ethnology of the Polish Academy of Sciences

W pięćdziesiąt lat później, z mniejszym rozmachem, odbyły się obchody „18,5 wieku Kalisza”, a także jubileusz w 50 lat po Millenium. Podkreślenia wymaga współpraca i zrozumienie dla archeologii w zakresie ochrony dziedzictwa kulturowego w kontaktach z władzami miasta, czego przykładem było wiele sympozjów, sesji, wystaw i tym podobnych przedsięwzięć.

Rocznice 1000-letnia oraz 1050-letnia na terenie Kalisza posłużyły do przygotowania badań, obchodów, wystaw (w tym stałych ekspozycji w MOZK) oraz utworzenia i zbudowania rezerwatu Kaliski Gród Piastów.

Pierwszy projekt rezerwatu archeologicznego w Kaliszu na Zawodziu powstał w roku 1960. Potem jeszcze kilkakrotnie tworzono następne koncepcje zagospodarowania tego terenu, aż w roku 2007 dzięki środkom uzyskanym z Europejskiego Funduszu Rozwoju Regionalnego zrekonstruowa- no zabudowania grodu i stworzono warunki do odpowiedniego zwiedzania tego obiektu. Wzniesiono obiekt, przy którego powstaniu z Muzeum Okręgowym Ziemi Kaliskiej jako inwestorem współpracował Instytut Archeologii i Etnologii PAN. Współpraca z MOZK w całej historii placówki Instytutu układała się bardzo dobrze, w jej zakresie zrealizowano wiele przedsięwzięć (Kozłowska 1956; Magdziński 2016; Pudełko 2016; Ziąbka 2016).

Kalisz jako miasto z wielkimi tradycjami historycznymi miał szczęście ze względu na powstanie tam silnego ośrodka naukowego, wyspecjalizowanego w bibliotekoznawstwie i tworzeniu bibliografii. Jest to zasługa m.in. Krzysztofa J. Walczaka, Ewy Andrusiak i Danuty Wańki, dzięki którym jest stosunkowo łatwo dotrzeć do publikacji naukowych i prasowych na określony kaliski temat (Andrysiak 2002-2007; Wańka 2016; Cyngot 2016). 


\section{BIBLIOGRAFIA}

Andrysiak E. (red.) 2002-2007. Bibliografia historii Kalisza. Kalisz.

Baranowski T. 1990. Krzysztof Dąbrowski - archeolog Kalisza. Rocznik Kaliski 22, 47-57.

Baranowski T. 2015. Zmienny obraz wczesnej historii Kalisza. Dowody i hipotezy. Rocznik Kaliski 41, 11-25.

Baranowski T. 2016a. Badania, postacie i odkrycia. 60 lat placówki archeologicznej PAN w Kaliszu. (W:) A. Kędzierski (red.), Wokół poczatków Kalisza. 60 lat stacji archeologicznej IAE PAN w Kaliszu. Warszawa-Kalisz, 11-23.

Baranowski T. 2016b. Kalisz w dobie Chrztu Polski. (W:) A. Kędzierski (red.), Wokót poczatków Kalisza. 60 lat stacji archeologicznej IAE PAN w Kaliszu. WarszawaKalisz, 137-153.

Baranowski T. 2016c. Badania millenijne w Kaliszu (wywiad). (W:) K. Zdeb (red.), Chrzest Polski w źródłach archeologicznych. Wywiady. Warszawa, 65-70.

Cyngot D. 2016. Literatura - archeologiczne kalisiana. (W:) A. Kędzierski (red.), Wokół początków Kalisza. 60 lat stacji archeologicznej IAE PAN w Kaliszu. Warszawa-Kalisz, 177-189.

Biliński B. 1955. Kalisia Ptolemeuszowa. Archeologia 5, 101-128.

Biliński B. 1962. Dwa świadectwa antyczne: Kalisia Ptolemeusza (Geographia II 11, 13) i Halisii Tacyta (Germania 43,2). (W:) A. Gieysztor (red.), Osiemnaście wieków Kalisza. Studia i materiały do dziejów miasta Kalisza i regionu kaliskiego 2. Kalisz, 7-51.

Dąbrowska I. 1960 Grodzisko na Zawodziu w Kaliszu. Pierwsze sprawozdanie z prac wykopaliskowych. (W:) A. Gieysztor (red.), Osiemnaście wieków Kalisza. Studia i materiaty do dziejów miasta Kalisza i regionu kaliskiego 1. Kalisz, 29-67, 366-367, 380-381.

Dąbrowska I. 1968. Badania archeologiczne na Zawodziu w latach 1961-1964. Rocznik Kaliski 1, 350-372, 426427, 438-439.

Dąbrowski K. 1958. Osadnictwo z okresów późnolateńskiego i rzymskiego na stan. 1 w Piwonicach, pow. Kalisz. Materiaty Starożytne 4, 7-89.

Dąbrowski K. 1962a. The more Significant Results of Archaeological Research in Kalisz and its Neighbourhood. Kwartalnik Historii Kultury Materialnej 10 (3). Ergon, 487-495.

Dąbrowski 1962b. Badania archeologiczne na Zawodziu (1959-1960). (W:) A. Gieysztor i K. Dąbrowski (red.) Osiemnaście wieków Kalisza. Studia i materiały do dziejów miasta Kalisza i regionu kaliskiego 3. Kalisz 53-90.
Dąbrowski K. i Kozłowska R. 1959. Dwie osady z okresów późnolateńskiego i rzymskiego we wsi Piwonice, pow. Kalisz. Materiały Starożytne 5, 283-329.

Drewko M. 1953. Prace badawcze na Tyńcu w Kaliszu w 1952 r. Sprawozdania P.M.A. V (1-2), 87.

Dąbrowski K., Stopiński W. i Stupnicka E. 1962. Początki i rozwój grodziska na Zawodziu w Kaliszu w świetle badań środowiska naturalnego. Archeologia Polski 7 (2), 203-228.

Herbich T. 2016. Krzysztof Dąbrowski w Kaliszu: o początkach polskiej geofizyki archeologicznej. (W:) A. Kędzierski (red.), Wokót początków Kalisza. 60 lat stacji archeologicznej IAE PAN w Kaliszu. WarszawaKalisz, 37-45.

Kędzierski A. (red.) 2016. Wokół poczatków Kalisza. 60 lat stacji archeologicznej IAE PAN w Kaliszu. WarszawaKalisz.

Kędzierski A., Wyczółkowski D. 2016. Stare Miasto Kalisz. 60 lat badań Instytutu Archeologii i Etnologii PAN. (W:) A. Kędzierski (red.), Wokót poczatków Kalisza. 60 lat stacji archeologicznej IAE PAN w Kaliszu. Warszawa-Kalisz, 81-103.

Kozłowska R. 1956. Wystawa Polowa Stacji Archeologicznej IHKM PAN w Kaliszu. Wiadomości Archeologiczne 23/1, 123.

Kozłowska R. 1968. Uroczystości 1000-lecia Państwa Polskiego i XVIII wieków Kalisza. Rocznik Kaliski 1, 397-399.

Lech J. 1997-1998. Between captivity and freedom: Polish archaeology in the 20th century. Archaeologia Polona 35-36 (Special theme: Archaeology in the 20th century. Ideas - people-research), 25-222.

Migdalski M. 2016. Rezerwat archeologiczny w Kaliszu-Zawodziu jako przykład współpracy Instytutu Archeologii i Etnologii PAN, Miasta Kalisza i Muzeum Okręgowego Ziemi Kaliskiej. (W:) A. Kędzierski (red.), Wokót poczatków Kalisza. 60 lat stacji archeologicznej IAE PAN w Kaliszu. Warszawa-Kalisz, 67-77.

Młynarska M. 1960a. Sprawozdanie z prac wykopaliskowych na terenie miasta lokacyjnego w Kaliszu 1955 r. Sprawozdania Archeologiczne 5, 173-182.

Młynarska M. 1960b. Kalisz średniowieczny. (W:) Szkice z dziejów Kalisza. Wrocław, 81-108.

Młynarska M. 1960c. Proces lokacji Kalisza w XIII i 1 poł. XIV w. (W:) A. Gieysztor (red.), Osiemnaście wieków Kalisza. Studia i materiaty do dziejów miasta Kalisza i regionu kaliskiego 1. Kalisz, 103-130.

Młynarska-Kaletynowa M. 1998. Kalisz w XI-XII wieku. (W:) T. Baranowski (red.), Kalisz wczesnośrednio- 
wieczny. Materiaty sesji, Kalisz 15 czerwca 1998. Kalisz, 13-27.

Młynarska-Kaletynowa M. 2000. Św. Paweł na grodzie kaliskim. (W:) S. Bylina (red.), Kościót, kultura, spoteczeństwo. Studia z dziejów średniowiecza i czasów nowożytnych. Warszawa, 77-85.

Przyłęcki M. 2006. Guerquin Bohdan. (W:) H. Kądziela, H. Krzyżanowska (red.), Polski stownik biograficzny konserwatorów zabytków 2. Poznań.

Pudełko E. 2016. Współpraca Muzeum Ziemi Kaliskiej ze Stacją Archeologiczną Instytutu Historii Kultury Materialnej PAN. (W:) A. Kędzierski (red.), Wokót poczatków Kalisza. 60 lat stacji archeologicznej IAE PAN w Kaliszu. Warszawa-Kalisz, 49-55.

Trawkowski S. 1962. Geneza regionu kaliskiego. (W:) A. Gieysztor, K. Dąbrowski (red.), Osiemnaście wieków Kalisza, t. 3, Kalisz, 7-51.
Wańka D. 2016. Archeologia w kalisianach. (W:) A. Kędzierski (red.), Wokót poczatków Kalisza. 60 lat stacji archeologicznej IAE PAN w Kaliszu. Warszawa-Kalisz, 157-173.

Wąsowiczówna T. 1960. Kalisz na tle wczesnośredniowiecznej sieci drogowej. (W:) A. Gieysztor (red.) Osiemnaście wieków Kalisza. Studia i materiały do dziejów miasta Kalisza i regionu kaliskiego 1. Kalisz, 69-101.

Ziąbka L. 2016. Współpraca Muzeum Ziemi Kaliskiej z Kaliskim Stanowiskiem Archeologicznym Instytutu Archeologii i Etnologii PAN w Warszawie. (W:) A. Kędzierski (red.). Wokół początków Kalisza. 60 lat stacji archeologicznej IAE PAN w Kaliszu. WarszawaKalisz, 59-63.

\section{TWO ANNIVERSARIES IN KALISZ (1960-1966): EIGHTEEN CENTURIES OF KALISZ AND MILLENNIUM OF POLAND}

\section{SUMMARY}

The Archaeological Laboratory of the Institute of Archeology and Ethnology of the Polish Academy of Sciences in Kalisz is over 60 years old and in all this time maintained its main profile of activity - research and activities focus on protection of cultural heritage and archaeological conservation for the sake of science and society of Kalisz. The text presents the participation of this section of the Institute in the implementation of undertakings connected with two jubilees - Millennium of the Baptism of Poland or Millennium of the Polish State and the Eighteen Centuries of Kalisz.

The strength of the Institute of the History of Material Culture was the interdisciplinarity of research, diversity and multiplicity of materials from the excavations, and existence of smaller units all over Poland, such as in Kalisz, which could practice many forms of activity, in constant contact with local society, including local authorities.

Long-term and highly fruitful excavations at the great archaeological site of the Roman period in Piwonice near Kalisz were carried out on a very large scale in the fifties. It was related to the role of archaeological sources in the identification of Kalisz as Ptolemy's Kalisia. In the same time, rescue work was carried out on many archaeological sites in Kalisz for example in the Old Town of Kalisz (in the years 1953-1957).
First manager head of the Archaeological Lab of IHKM PAN in Kalisz was Michał Drewko. The real animator and "soul" of the archaeological work in Kalisz was Krzysztof Dąbrowski, the head of this section for 20 years. He became director of the Lab in Kalisz in 1954, remaining on this post until 1974, when he assumed the office of Director of the State Archaeological Museum at Warsaw.

The greatest discoveries of the fifties and sixties of the 20th century in Kalisz concerned the research of Krzysztof and Iwona Dąbrowski in the area of Zawodzie-Stronghold. These researchers have confirmed the significant role of Kalisz as one of the main centers of early medieval Poland, provided a vast number of objects, artifacts etc., they directed also dozens of archaeological and accompanying interdisciplinary studies in the Kalisz region.

An important summary of a stage in the development of research on the past of Kalisz was the celebration of the "Eighteen Centuries of Kalisz" (1960) and "Millennium of the Polish State (1966). Cooperation with society of the city was exemplary and understanding on the field of archeology for the protection of cultural heritage always very supportive, as evidenced by symposia, sessions, exhibitions and similar events. 
Adres Autora:

Dr hab. Tadeusz Baranowski

Ośrodek Interdyscyplinarnych Badań Archeologicznych

Instytut Archeologii i Etnologii PAN

Al. Solidarności 105

00-140 Warszawa

e-mail: thaddeus@iaepan.edu.pl 